\title{
木造軸組工法耐力壁の静的・動的性状に関する実験的研究 \\ EXPERIMENTAL STUDY ON STATIC AND DYNAMIC PROPERTIES OF SHEAR WALLS OF WOODEN POST AND BEAM CONSTRUCTION
}

\author{
町田健 一*1, 綿引誠*1, 大橋好光*2, 坂本 功*3 \\ Kenichi MACHIDA, Makoto WATAHIKI, Yoshimitsu OHASHI \\ and Isao SAKAMOTO
}

\begin{abstract}
Static and dynamic loading tests were carried out in 8 types of shear walls of wooden post and beam construction. Comparative analyses of the results proved the followings with regard to "static and dynamic properties" and "influence of cyclic loading". In the all types, the dynamic load exceeded 1.1-1.5 times as much as the static load even in small displacement. Regarding the maximum load, the static and dynamic loads were almost the same in wooden elements, and the dynamic load was larger than the static load in inorganic elements. " $\delta u$ " of the all types and " $\delta y$ " of the wooden elements were smaller under the dynamic load than under the static load. The failure type of wooden boards changed from "pull-out of nails" to "mixture of punch-outs" under the dynamic load, and the others had no change in the static and dynamic loads. Through the influence of cyclic load, the maximum load of the static loading test of plywood and inorganic boards decreased at $10 \%-20 \%$ range.
\end{abstract}

Keywords : Wooden Post and Beam Construction, Shear Wall, Static Loading Test, Dynamic Loading Test 木造軸組工法、耐力壁、静的加力試験、動的加力試験

1.はじめに

1995 年の「阪神・淡路大震災」を機に、木造軸組工法住宅の耐 震性能は大きな進化を遂げている。震災による 6,400 人を上回る 犠牲者の内、 8 割近くは压死によると推定され、大部分は倒壊した 建物の下敷きになったためと考えられている。大きな被害が発生 した建物は古い構法のものや耐力壁が少ないものであったとの原 因分析 ${ }^{2)}$ がなされている。建物の部位のうち耐力壁が耐震性能に 大きな役割を果たしていることは明白である。耐力壁に対しては 単に量的な要求の他に、より優れた性能への質的な要求がありそ れを満足させるべく改良が行われているが、その性能の見極め方 も重要である。

現在、2 階建てまでの木造住宅は建築基準法施行令 46 条による いわゆる壁量規定ルートによって設計されており、耐力壁の性能評 価は「壁倍率」を基本に行われているのが一般的である。壁倍率を 求める具体の試験法及び評価法は、各性能評価機関の業務規定 ${ }^{3)} の$ 中で定められており、加力方法として静的正負交番同一履歴 3 回繰 り返し加力が用いられている。

ここで実際に建物に加わる外力を想定すると、地震動は言うまで
もなく動的なものであるため、静的試験による評価が安全側である か否かの判断、つまり静的性状と動的性状の違いを把握することは 重要である。また、一方向単調加力についても、直下型地震や風荷 重などの一方向に大きく加わる力を想定すると、その性状を把握し ておくことは重要である。

耐力壁の静的・動的性状に関する既往の研究として、山田ら ${ }^{4)}$ は 笳かい・合板・貫・土壁耐力壁と軸組フレームについて実験を行い、 土壁と軸組フレームで層間変形が 0.02rad. を超えると動的実験が 静的実験の復元力を上回ると荷重速度の影響を報告している。ま た、箕輪ら ${ }^{5)}$ は合板耐力壁について動的が静的繰り返しの 1.09 倍の 最大荷重を示し、最大荷重時の変形角は動的が静的の 72\%であると 報告している。

一方で耐力壁自体の仕様に目を向けると、従来一般的であった 筋かいや構造用合板に代表される木質系面材に加え、例えば窑業 系面材のような防火性能を合わせ持つといった多機能を特徽とし た新しい耐力壁が多数上市されている状況や、間仕切壁に多用さ れ建物全体の耐震性能への影響が大きい石霄ボード ${ }^{6)}$ も含め、耐 力壁仕様の違いによる性状を把握することも重要である。 
以上の研究背景に基づき、本研究は、5種類 8 仕様の木造軸組工 法耐力壁に対して、静的加力と動的加力の 2 種類の加力方法につい てそれぞれ繰り返しと単調の合計 4 種類の試験を行い、「静的加力 と動的加力の違い」と「繰り返しの影響」について試験結果を比較 分析したものである。

\section{2. 研究方法}

\section{1 耐力壁仕様}

表 1 に試験に用いた耐力壁の仕様と建築基準法等で規定されて いる壁倍率の一覧を示す。笳かい（B と呼ぶ）は、半割の片筋かい $(45 \times 105 \mathrm{~mm}$, 逆八の字型）とした。石高ボード（G と呼ぶ）は、 厚さ $12.5 \mathrm{~mm}$ で面材下部を床勝ち納めとした。面材高さを横架材間 の内法寸法 2,710 m に対して $2,520 \mathrm{~mm}$ と低く設定し住宅の品質確 保の促進等に関する法律における準耐力壁仕様とした。壁倍率は 同法律の規定により面材高さと横架材間の内法寸法との比を全壁 の壁倍率 (0.6 倍) に乗じて求めた。構造用合板は厚さ $9 \mathrm{~mm}$ とし、 JAS 特類 1 級（P1）と 2 級（P2）の 2 仕様とした。筀業系の火山性 ガラス質複層板は、建物外周部に使用される厚さ $9 \mathrm{~mm}$ ・釘留めの 仕様 (Dms) と建物内部に使用される厚さ $12.5 \mathrm{~mm}$ ねじ留めの仕 様を床勝ち納め (Dmk) とした 2 仕様とした。小幅板斜め貼合せ面 材は、厚さ $9 \mathrm{~mm} \times$ 幅 $55 \mathrm{~mm}$ の小幅板を斜め 45 度の格子状に貼り合 わせた面材で、小幅板の樹種として杉（Ks）と桧（Kh）の 2 仕様 とした。従って、全体で合計 5 種類 8 仕様の試験体を用意した。 木質系面材は構造用合板 (P1, P2) と小幅板斜め貼合せ面材 (Ks, Kh) の 2 種類 4 仕様で、これに火山性ガラス質複層板（Dms, Dmk）を加 えた 3 種類 6 仕様が、壁倍率の規定值が同じ 2.5 倍である。耐力 壁の試験結果から軸組フレームの影響を除くため、軸組フレーム

（F）も静的・動的について試験を実施した。軸組には集成材を用 いた。共通仕様や集成材の比重と含水率の平均值 $(\mathrm{P} 1 \cdot \mathrm{Kh}$ に使用し たもの）を表 1 に示す。また、面材はいずれも縦継ぎの不要な長 尺品を使用した。面材を留める釘やねじの施工は、破壊性状に影 響を及ぼす恐れがあるため、全ての仕様で手打ち施工とし、釘や ねじの頭が面材の面と同一となるように施工した。

\section{2 試験構成}

試験構成を図 1 に示す。静的加力試験（写真 1 ）は、正負交番同 一履歴 3 回繰り返し加力 (S1 と呼ぶ) と一方向単調加力 (S2 と呼ぶ) の 2 種類とし、繰り返しの影響が直接分かる構成とした。

動的加力試験（写真 2）は、1 軸小型振動台を用いて行った。入 力に用いた地震波は、特に大きな振幅が一撃で発生するような特徵 を持った直下型地震の例として「JMA-KOBE-NS 波：記号 DK」と、大 きな振幅が何回か繰り返すような特徵を持った海溝型地震の例とし て「EL Centro-NS 波 : 記号 DE」の 2 種類を用い地震波特性の違いを 比較できる構成とし、地震波毎に 2 種類の加振を行った。一つは入 カ波のスケール（基淮波に対する振幅比率）を 5〜20\%刻みで徐々に
表 1 耐力壁仕様一覧

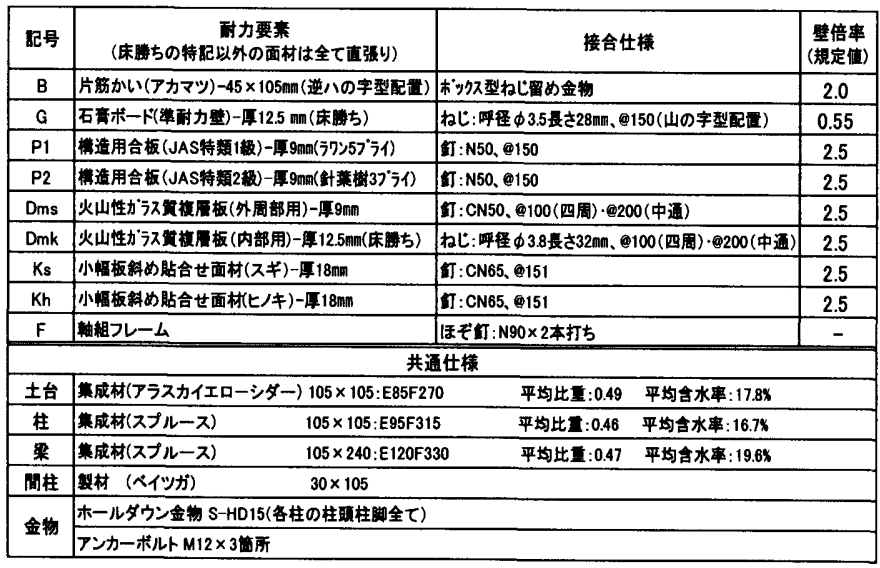

\begin{tabular}{|c|}
\hline S1: 正負交番同一履歴3回縟り返し加力 \\
\hline S2:一方向単調加力 \\
\hline
\end{tabular}

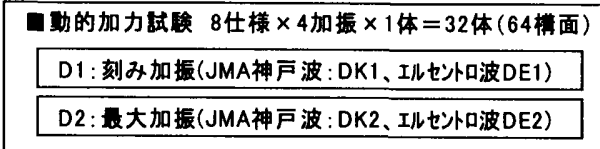

図 1 試験構成

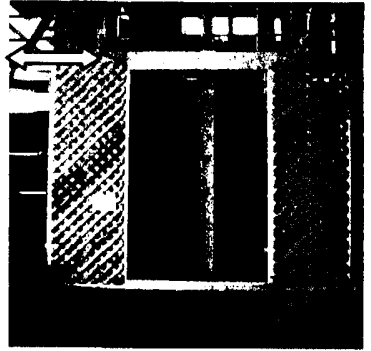

写真 1 静的加力試験全景

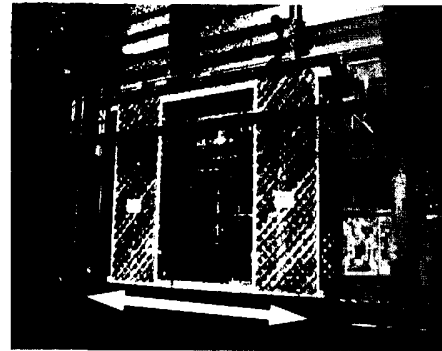

写真 2 動的加力試験全景

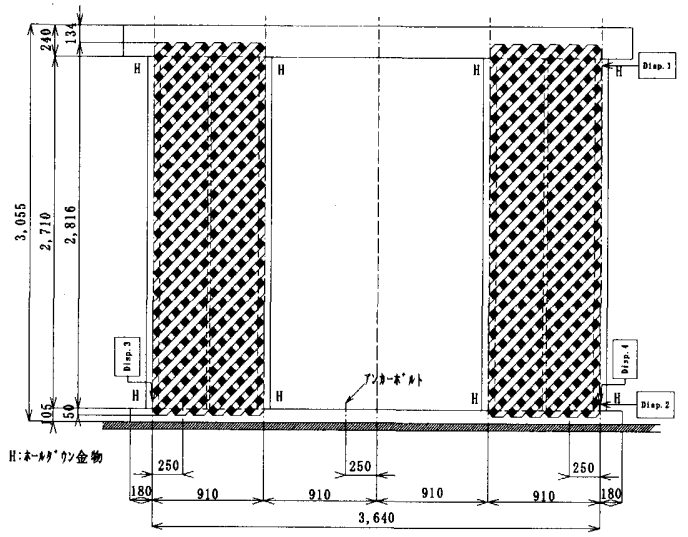

図 2 、試験体図

大きくして何回も加振する「刻み加振：記号 1」、もう一つは破壊に 相当するような大きなスケール（基本的に刻み加振における最大ス ケール）を一気に加える「最大加振：記号 2」とした。刻み加振は 小さい振幅から大きい振幅まで徐々に入力を重ねることで繰り返し の回数が多くなり、最大加振と比較することで繰り返しの影響が分 かる構成とした。以上の試験を図 2 に示す共通の大きさの試験体に 対して実施した。 


\section{3 静的加力試験概要}

試験体は、各耐力要素を両端のグリッドに配置した幅 $3,640 \mathrm{~mm}$ 、 高さ 3,055 mmの壁試験体である。試験方法は柱脚固定式（無載荷） の面内せん断試験とし、全ての柱頭柱脚にホールダウン金物（S-HD 15）を設置し、土台の 3 カ所をアンカーボルトで試験機に緊結した。 繰り返し加力（S1）の制御は、見かけのせん断変形角（1/600,1/45 $0,1 / 300,1 / 200,1 / 150,1 / 100,1 / 75,1 / 50 \mathrm{rad}$.$) を基準として 3$ 回ず つ繰り返し、最終的には $\mathrm{S} 1 \cdot \mathrm{S} 2$ 共に最大荷重を記録した後、最大荷 重の $80 \%$ 荷重に低下するか若しくは 1/15 rad.を超えるまで押し 側に加力した。加力速度は概ね $0.05 〜 0.1 \mathrm{kine}$ である。

\section{4 動的加力試験概要}

各試験体一入力した地震動のスクールと加振回数を表 2 に示す。 加振回数とは、一つの試験体に対して最大荷重の $80 \%$ の荷重に低下 するか若しくは 1/15 rad. を超えるまでに要した加振の回数である。 振動台の制御精度は振幅が目標波の 80〜90\%であったが、周波数特 性は基準波と概ね同じだった。

試験体の仕様は静的加力試験と同じである。但し、試験を安定的 に行なうために 2 つ壁試験体を $910 \mathrm{~mm}$ 幅で並列に配置し剛床を兼 ねた錘架台（写真 3 ）で梁上を連結した箱形の試験体とした。全て の柱頭柱脚にホールダウン金物（S-HD15）を設置し、直交側は合板 による振れ止めを設けた。試験体の挙動は、サーボ型加速度計とレ 一ザー変位計およびワイヤー巻取り式変位計を用いて各部を計測し た。架台を含めた錘の重量は、試験機の加振能力の関係から耐力壁 の仕様によらず $50.8 \mathrm{kN}$ に統一した。壁倍率 1 あたりの基準耐力 1.9 $6 \mathrm{kN} / \mathrm{m}$ から層せん断力係数 C を求めると、壁倍率 2.5 で $\mathrm{C}=0.35$ に相 当する量であり、建築基準法で規定される $\mathrm{C}=0.2$ より耐力壁が多い 設定である。但し、試験体の固有振動数を常時微動で測定したとこ ろ、4〜 7Hz の範囲にあり近年の木造軸組工法住宅の特性に近いもの であった。また、柱 1 本当たりの平均負担重量は $6.35 \mathrm{kN}$ で十分設計 の範囲内にある。

\section{3. 静的加力試験結果および考察}

\section{1 解析方法}

変形評価は見かけのせん断変形角を用いた。荷重の評価には軸組 フレームの影響を除くため、図 3 に示すように各耐力壁の荷重から 別試験で求めた軸組フレームのみの荷重を差し引いて評価すること とした。具体的には $0.1 \mathrm{mrad}$.ピッチの単位変形量に対応した荷重を 直線補完によって求めた後、軸組フレーム分を単純に差し引いた。

\section{2 荷重変形関係}

\section{a ) 綝り返しの影響}

図 4 に静的繰り返し加力（S1）と単調加力（S2）の押し側の包絡 線を、表 3 に特定変形角時荷重と荷重比 $(\mathrm{S} 1 / \mathrm{S} 2)$ を示し、次に各仕 様の特徴を示す。

・筋かい（B）：1/75rad. 付近まで差はなく、繰り返しの影響は見ら

表 2 動的加力試験一入力スケールと加振回数

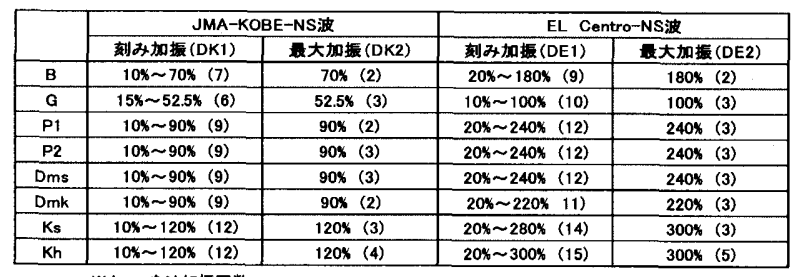

※かッコ内は加摄回籹

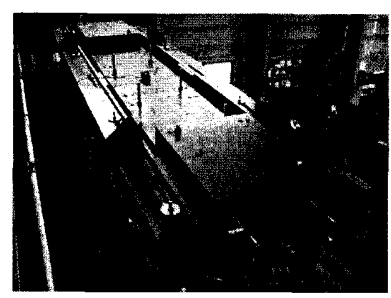

写真 3 鍾架台
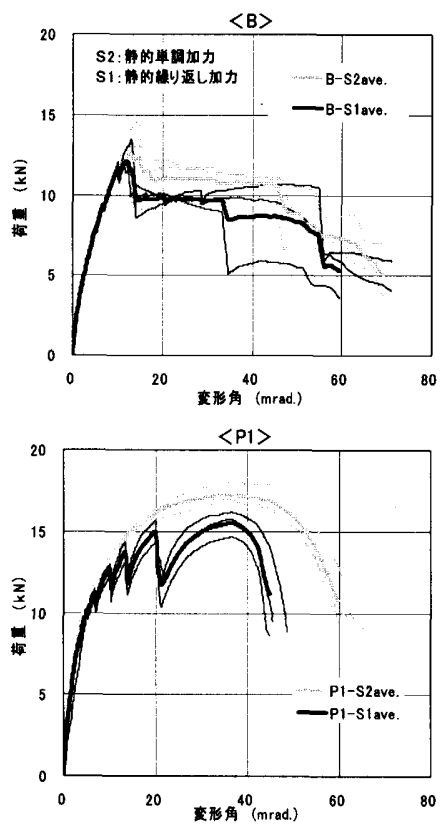

<Dms>

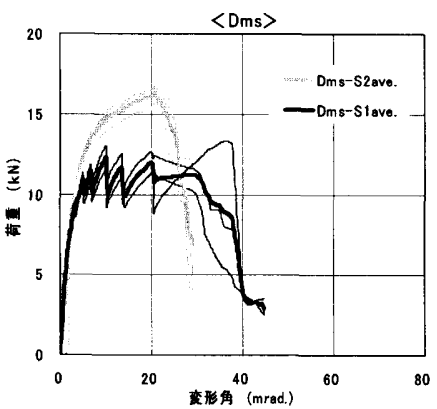

$\langle\mathrm{Ks}\rangle$

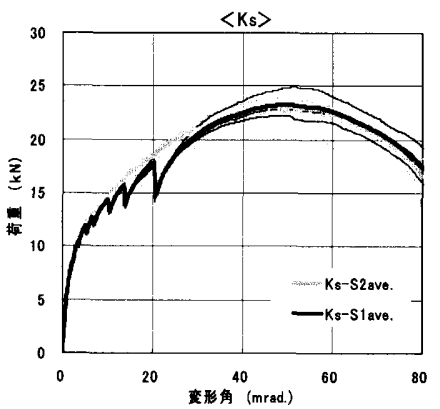

図 4 静的加力試験一荷重変形関係 $<\mathrm{S} 1 \cdot \mathrm{S} 2$ の比較 $>$

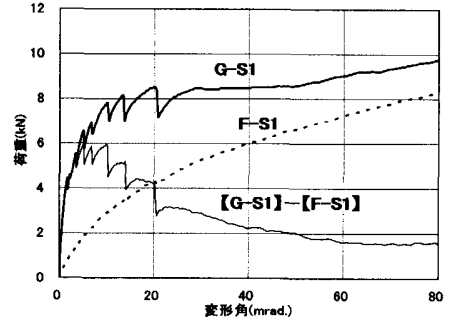

図 3 軸組フレームの影響

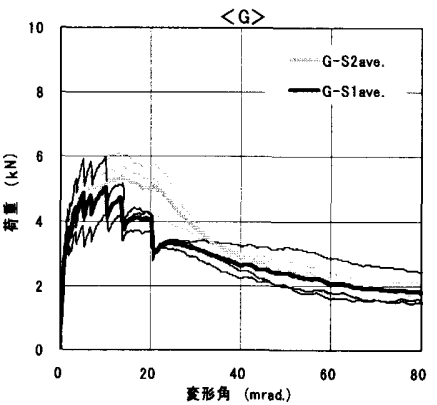

$\langle\mathrm{P} 2\rangle$

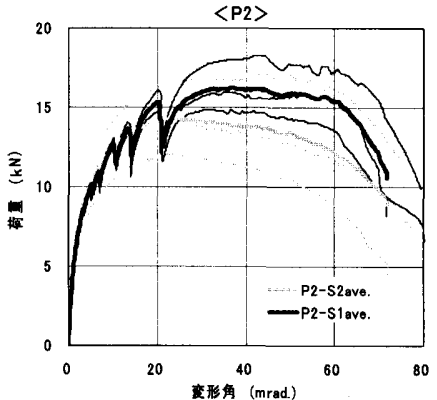

<Dmk $>$

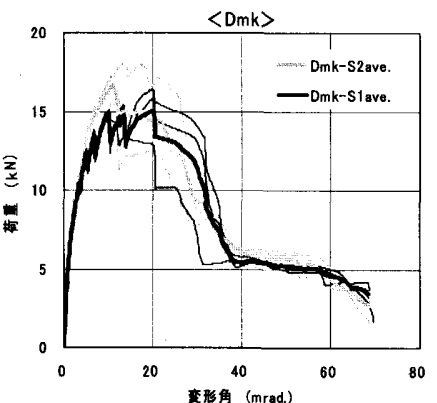

$\langle\mathrm{Kh}\rangle$

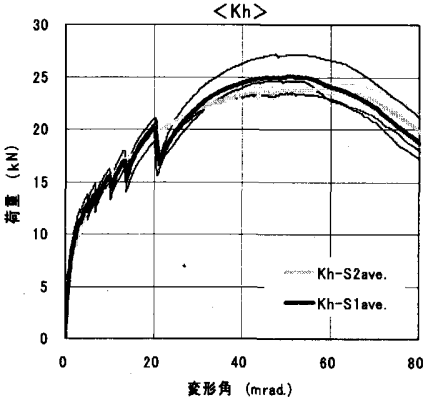


れない。その後はいずれの試験体も間柱の割裂をきっかけに圧 縮筋かいのはらみ出しで荷重低下するため繰り返しの影響は 明確では無い。

・石亮ボード（G）：ばらつきが大きい。1/100 $\mathrm{rad}$. 付近から徐々 にS1 が下回り最大で 19\%低下し、繰り返しの影響が見られた。

・構造用合板（P1·P2）：P1 はばらつきがほとんど無く、S1 の荷 重が初期で約 $15 \%$ 、最大荷重で 10\%下回り繰り返しの影響が若 干見られた。P2 は S2 のばらつきが特に大きく平均值で比較す ると $1 / 75 \mathrm{rad}$. 付近より逆にS2 の荷重が $10 \%$ 程度低下した。

- 火山性ガラス質複層板 (Dms.Dmk) : 1/200 rad. 付近より徐々に S1 の荷重が低下し、Dms では最大荷重で $21 \%$ 下回り、繰り返し の影響が最も大きく現れた。Dmk-S2 の最大荷重時変位が Dms-S2 より小さいのは、床勝ち納まりによって面材の割れが発生した ことが原因である。その影響を除けば Dms と同じ性状と推定さ れる。

・小幅板斜め貼合せ面材 $(\mathrm{Ks} \cdot \mathrm{Kh})$ ：ばらつきはほとんど無く、綎 り返しの影響も見られない。

\section{b）耐力要素による比較}

図 5 に繰り返し加力 (S1)における各耐力要素の 3 体平均の押し 側包絡線をまとめて示し、次に各仕様の特徽を示す。

・筋かい（B）：面材系に比べ初期剛性が低く、1/75rad. 付近から 筋かいのはらみ出しで荷重が一旦低下するものの、その後はは らみだしの増加と共に粘り強く推移する。

・石高ボード (G) : 初期剛性は他の面材耐力壁に匹敵する程高い が 1/100rad. 付近で最大荷重となりその後の荷重低下は早い。

・構造用合板 (P1·P2)：P2 は粘り強い性状を示すものの、P1 は釘の パンチアウト（釘頭貫通破壊）が発生するため最大荷重後の荷重 低下が比較的早い。

・火山性ガラス質複層板（Dms·Dmk）：剛性は他の面材より高いが、 最大荷重の発現が比較的早く、また最大荷重後の荷重低下も早い。 ・小幅板斜め貼合せ面材 $(\mathrm{Ks} \cdot \mathrm{Kh})$ ：壁倍率（規定值）が同じ 2.5 倍 の仕様の中で最も高い耐力を示した。

\section{3 静的破壊性状}

いずれの試験体も繰り返しの影響による最終的な破壊性状の違い は見られなかった。次に各仕様の特徵を示す。

-笳かい（B）：圧縮側では、筋かい取合間柱の割裂後、筋かいが面 外へはらみ出し座屈破断が発生した。実際の建物では面材による 座屈止め効果がある。引張側では筋かい金物のねじが拔け出した。

・石育ボード (G)：ねじパンチアウト及びねじ周りの面材縁切れ， 床勝ち部で面材が床板と干涉し圧壊した。

・構造用合板（P1・P2）：P1 は数本の釘引き抜けが発生するがほとん どの釬がパンチアウトするため、最大荷重後の早期荷重低下に慗 がったと推定出来る。P2 は全く逆の構成で釷の引き抜け過程で粘
表 3 静的加力試験一繰り返し加力と単調加力の荷重比

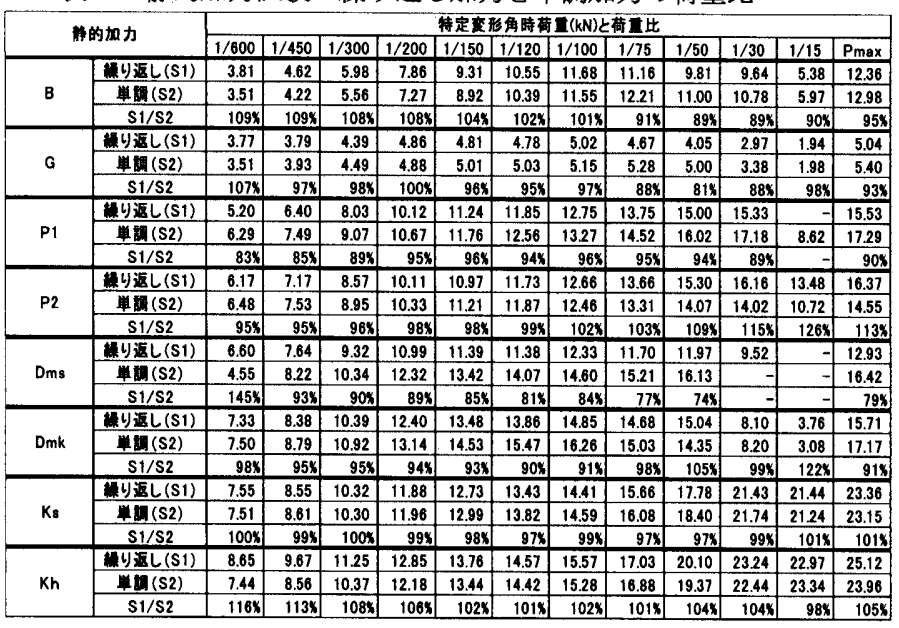

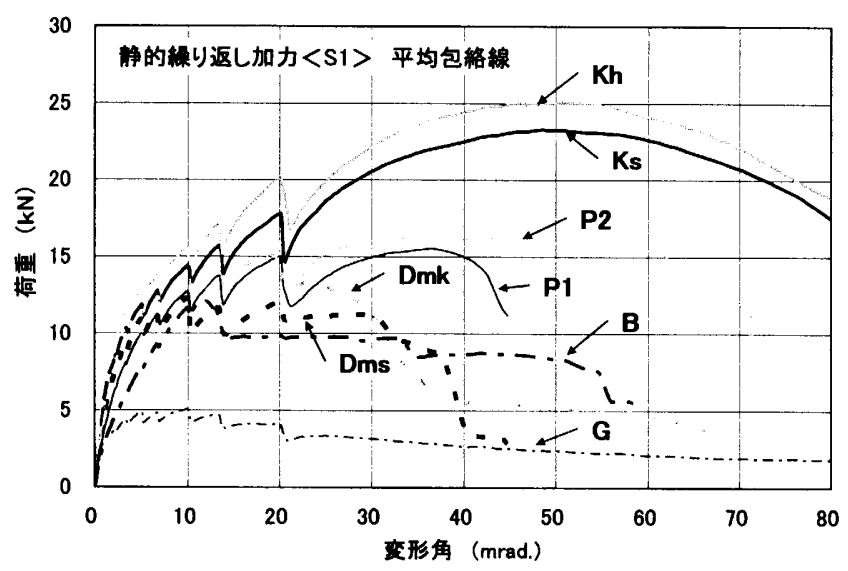

図 5 静的加力試験一荷重変形関倸 <耐力壁仕様の比較>

り強い性状を示したと推定出来る。

・火山性ガラス質複層板 (Dms·Dmk)：釘やねじのパンチアウトや一 部面材縁切れ，面材の割れで破壊。

・小幅板斜め貼合せ面材 $(\mathrm{Ks} \cdot \mathrm{Kh})$ : 釘頭が面材に大きくめり込みな がら引き抜けるのが特徴。釘の引き抜け主体だが、パンチアウト も発生した。

\section{4. 動的加力試験結果および考察}

\section{1 解析方法}

荷重は、錘を含めた試験体の上半分の質量に鍾架台位置で計測し た加速度を乗じて求めた。また、静的加力試験と同様に別試験で求 めた軸組フレーム荷重を差し引くと共に、静的加力試験と比較する ため 1 構面分の荷重（全体の 1/2）に変換した。変形は、試験体頂 部と振動台の絶対変位の差から求めた見かけのせん断変形角を用い た。荷重変形の包絡線は加振毎のデータをすべて連結して求めた。

\section{2 荷重変形関係}

\section{a）試験方法による比較}

図 6 に各耐力要素の動的加力試験の包絡線を示す。2 種類の地震 波による違いが現れたのは小幅板斜め貼合せ面材（Ks·Kh）のみで、 JMA-KOBE-NS 波を使用した加振(DK1, DK2)の方が EL Centro-NS 波を 
使用した加振 (DE1, DE2) よりも荷重が 10\%程度上回った。その他の仕 様は、初期はほぼ同等で塑性化するに従いばらついた。また、2 種 類の加振方法について比較すると、刻み加振 (DK1, DE1) の方が最大加 振 (DK2, DE2) よりも若干荷重が小さい傾向が見られたが、顕著な差は なく概ね同じであった。

\section{b）耐力要素による比較}

図 7 に動的加力試験の 4 体平均 (DK1, DK2, DE1, DE2)の包絡線を示 し、次に各仕様の特徴を示す。

-筋かい (B) : 1/100rad. 付近の比較的小さい変形角から圧縮筋かい が面外にはらみ出して座屈破断が発生し荷重低下した。

・石亳ボード（G）：初期剛性は高いが約 1/100rad. と早い段階で最 大荷重を迎え、その後の荷重低下も比較的早い。

-構造用合板 $(\mathrm{P} 1 \cdot \mathrm{P} 2)$ ：荷重は小幅板斜め貼合せ面材の $70 \sim 80 \%$ 程 度であるが、同じように粘り強い性状を示す。

・火山性ガラス質複層板（Dms·Dmk）：初期の剛性は高いものの、最 大荷重の発現が 1/100 1/50rad.の間と早く、その後の荷重低下 も比較的早い。

・小幅板斜め貼合せ面材 $(\mathrm{Ks} \cdot \mathrm{Kh}) ： 5$ 種類の中で最も耐力が高く、 塑性後の変形能力も大きい。

\section{3 動的破壊性状}

動的破壊性状は、構造用合板（P2）と小幅板斜め貼合せ面材 (Ks. Kh）において、静的に比べて破壊性状が変化した。その他の要素で は静的との違いは無かった。

・構造用合板 $(\mathrm{P} 1 \cdot \mathrm{P} 2)$ ：P1 は釘のパンチアウトで静的と変わりない が、P2 では釘の引き抜けと合わせ DE1 と DE2 で釘のパンチアウト が多数混在した。

・小幅板斜め貼合せ面材 $(\mathrm{Ks} \cdot \mathrm{Kh})$ ：釘頭がめり込みながら引き抜け 最終的な破壊として釷の引き抜けが主体であるのは静的と変わ りないが、DK1、DK2 でパンチアウトが多数混在した。

\section{5. 静的と動的の比較}

\section{1 荷重変形関係}

図 8 に静的試験（S1·S2）と動的試験（D）の平均包絡線を、表 4 に荷重比（D/S1）を示す。動的荷重（D）は全ての仕様で小変形領域 から静的荷重（S1）を概ね 1. 1 1.5 倍上回った。最大荷重は、木質 系要素 $(\mathrm{B} \cdot \mathrm{P} 1 \cdot \mathrm{P} 2 \cdot \mathrm{Ks} \cdot \mathrm{Kh})$ では静動によらずほぼ同等で、無機系要素 (G・Dms·Dmk) では動的が上回る傾向であった。木質系面材 (P1·P2 $\mathrm{Ks} \cdot \mathrm{Kh})$ の最大荷重は、動的の方が小さな変形角で発生した。次に各 仕様の静的絽り返し（S1）に対する動的（D）の特徽を示す。

・筋かい (B) : 最大荷重を記録する $1 / 100 \mathrm{rad}$. 付近まで動的荷重が 10 〜30\%上回った。その後、動的荷重は急激に低下し逆転した。 ・石亳ボード (G) : 最大荷重を記録する 1/100 rad. まで動的荷重が 3 0〜 50\%上回った。これは各耐力要素の中で最も高い割合である。
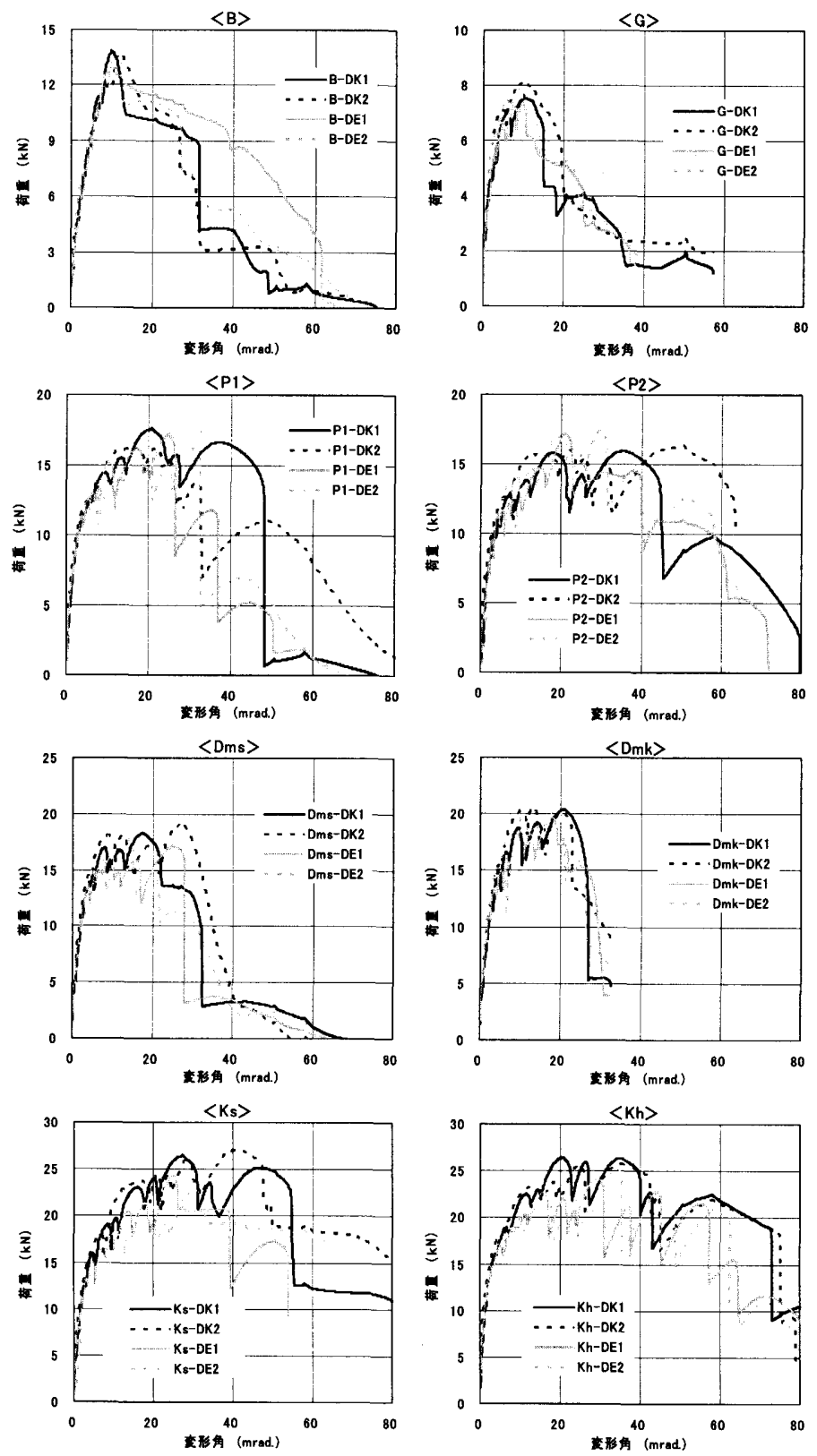

図 6 動的加力試験一荷重変形関係 $<\mathrm{DK} 1 \cdot \mathrm{DK} 2 \cdot \mathrm{DE} 1 \cdot \mathrm{DE} 2$ の比較 $>$

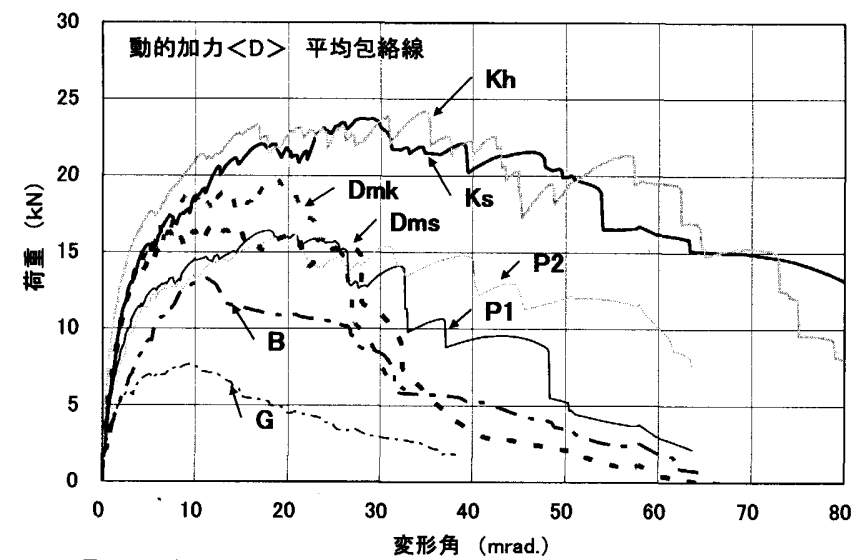

図 7 動的加力試験一荷重変形関倸 <耐力壁仕様の比較 > 
但し、その後は低下し $1 / 50 \mathrm{rad}$. 付近で静的荷重と同等となった。 ・構造用合板（P1·P2）：1/50 rad. 付近まで動的荷重が 5 20\%上回 る。その後 1/50rad. を超えると逆転し動的が静的を下回った。特 にP1 の荷重低下は急激である。最大荷重は動的の方が若干上回 る程度で、最大荷重時変形角は動的の方が小さい。

・火山性ガラス質複層板（Dms）：1/30rad. 付近まで動的荷重が 30〜 40\%と大きく上回る。その後どちらも比較的早く低下した。

・火山性ガラス質複層板（Dmk）:1/50 rad，付近まで動的荷重が 20 〜30\%と大きく上回る。その後どちらも比較的早く低下した。

・小幅板斜め貼合せ面材 $(\mathrm{Ks} \cdot \mathrm{Kh}): 1 / 50 \mathrm{rad}$. 付近まで動的荷重が 20 〜40\%と大きく上回る。その後 $1 / 30 \mathrm{rad}$. を超えると逆転し動的が 静的を下回った。最大荷重は動的の方が若干上回る程度であるが、 最大荷重時変形角は動的の方が明らかに小さい。

\section{2 完全弾塑性モデル}

\section{a) モデル化の目的}

試験方法の違いによる傾向を定量的に把握する目的で、建築基準 法施行令第 46 条第 4 項表 1 の（八）に基づく木造軸組工法耐力壁の 評価方法 ${ }^{7)}{ }^{8)}$ である完全弹塑性モデルを用いて比較した。完全弾塑 性モデルは、試験体毎に求め、三つの試験方法別に平均し比較した。 動的加力試験の 4 体の試験体は入力波などが異なるが、同じ動的の 試験としてまとめた。試験体毎に求めた完全弾塑性モデルを試験方 法別に平均したものを図 9 に、完全弾塑性モデルと包絡線の特徽点 の值を試験方法別に平均した一臨を表 5 に示す。特徽点の中から降 伏耐力 $(\mathrm{Py})$ 、降伏変位 $(\delta \mathrm{y})$ 、終局耐力 $(\mathrm{Pu})$ 、終局変位 $(\delta \mathrm{u})$ 、 剛性 $(\mathrm{k}) 、$ 構造特性係数 (Ds) について、試験方法別に比較したも のを図 10 に示す。次に考察を述べる。

\section{b ）壁倍率の評価項目}

表 5 ○印の四つの項目は、壁倍率の算出に用いる評価項目である。 壁倍率は、この評価項目の值にそれぞれのばらつき倸数（母集団を 正規分布と見なし統計的処理に基づく信頼水準 75\%の 50\%下側許容 限界をもとに求めた值）を乗じて得た值の最小值に、材料の耐久性 や施工の影響等を勘案して仕様毎に設定された低减俰数を乗じ、最 後に壁倍率の基淮耐力（1.96kN/m/倍）で除して求めると規定 $\left.{ }^{3 ）} 7\right)$ されている。ここでは試験方法別の比較を目的とし、動的加力試験 の 4 体の試験法が異なることや仕様によって低減係数が異なること などからばらつき係数や低減保数は考虑せず静的加力試験も含め全 て試験方法別の平均值で示した。また、動的加力試験の 4 体を同じ 試験法と見なし、前述のばらつき係数を考慮しても本節の結論は変 わらないことも確認した。

壁倍率を求める試験法である静的正負交番 3 回繰り返し加力試験 （S1）の評価項目の最小值に対して、静的一方向単調加力試験（S2） と動的加力試験（D）の值が上回る関係であれば、現状の壁倍率は加 力方法によらず安全側の評価と判断でき、その比率は安全率に相当
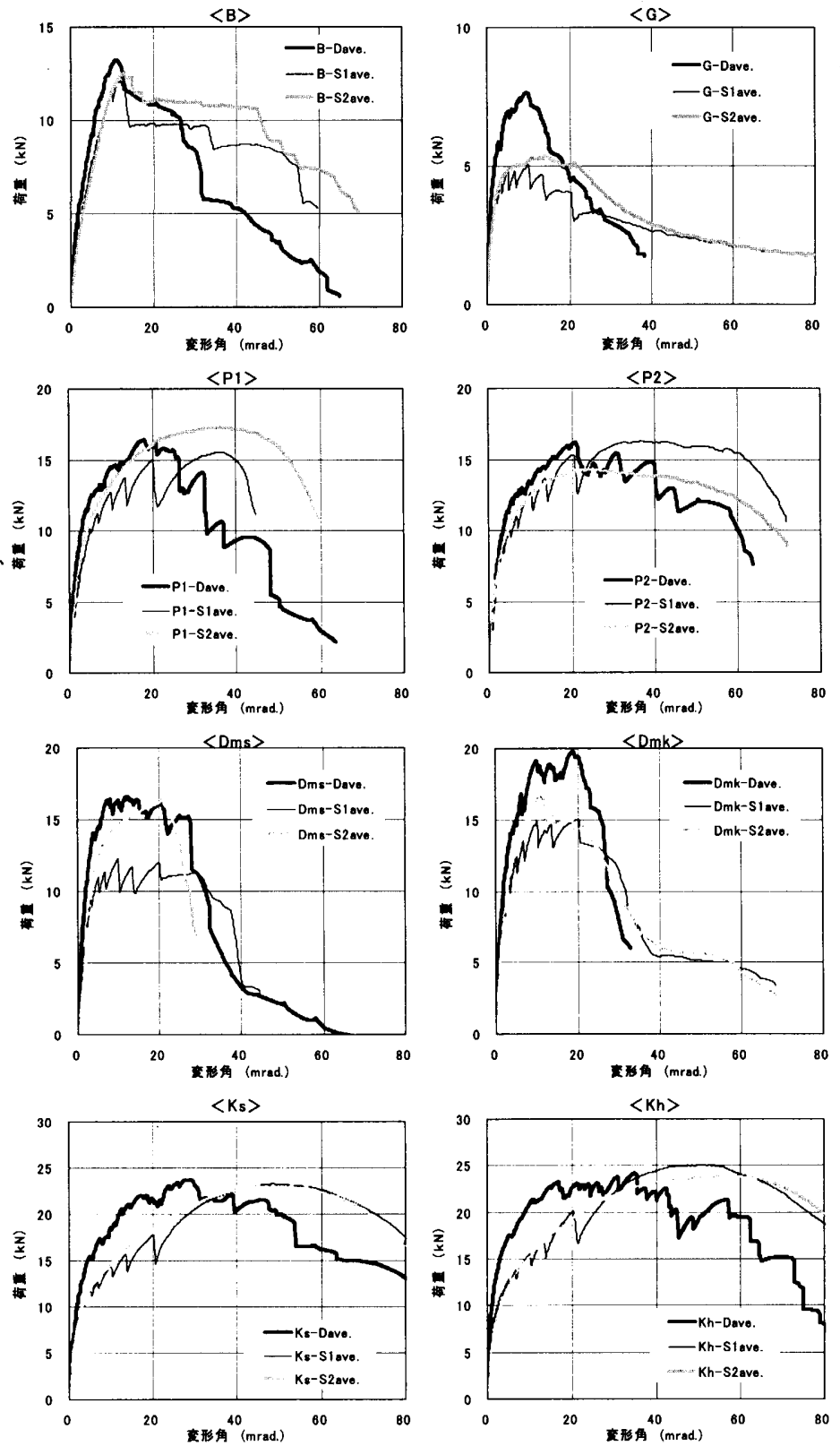

図 8 荷重変形関係 <静的と動的の比較>

表 4 静的加力と動的加力の荷重比

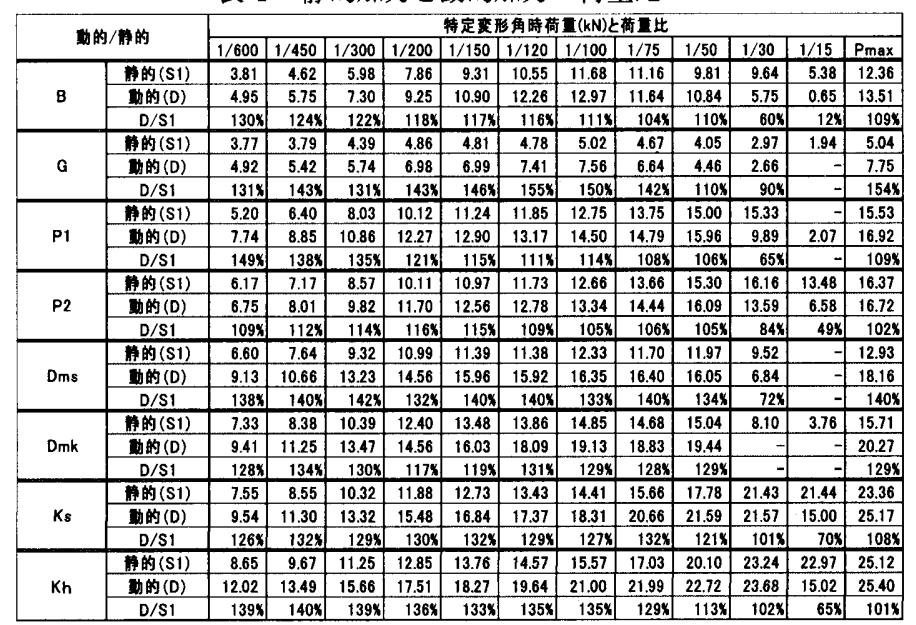


する。表 5 の太枠は評価項目の中の最小值を示し、網掛けは S1 の最 小值を下回る場合を示す。動的加力試験（D）の值は、全ての仕様で 静的繰り返し試験（S1）の最小値を上回り、安全率は概ね 1.3 倍の 範囲にあることが分かった。静的単調加力（S2）の值は、5 仕様（G. $\mathrm{P} 2 \cdot \mathrm{Dmk} \cdot \mathrm{Ks} \cdot \mathrm{Kh})$ で S1 の最小值を若干下回り、注意を要することが分 かった。火山性ガラス質複層板 (Dmk) の場合は、繰り返し加力の影 響で荷重が徐々に低下する性状から、単調加力において繂り返し加 力の影響が無いために上昇した荷重が早くに低下する性状となった。 その影響で構造特性保数（Ds）が 0.29 から 0.35 と大きくなり最小 值の評価項目が Py から Pu・ (0.2/Ds) に変わった結果、S2 が若干下回 った。Dms-S2 も同じ性状である。構造用合板（P2）と小幅板斜め貼 合せ面材（Kh）は、同じ評価項目の Py の中で S2 が若干下回った。 Py には最大荷重及び最大荷重までの荷重変形関保が影響するが、P2 と Khの S2 はこれらが S1 と比べ若干低かった。また、石衰ボード (G) と小幅板斜め貼合せ面材（Ks）は、顕著な差ではない。

\section{c) 降伏耐力（Py）と降伏変位 $(\delta y)$}

降伏耐力（Py）は、全ての仕様で静的試験（S1·S2）よりも動的試 験（D）の方が高く、1.1〜1.4 倍程度の動的安全率があることが分 かった。特に無機系要素 (G・Dms・Dmk) は 1.3〜1.4 倍と高く、次い で筋かい (B) と小幅板斜め貼合せ面材 $(\mathrm{Ks} \cdot \mathrm{Kh})$ が 1.15〜1.2 倍で、 構造用合板 $(\mathrm{P} 1 \cdot \mathrm{P} 2)$ は 1.1 倍であった。降伏変位（ $\delta \mathrm{y} ）$ は、特に 木質系要素（B・P1・P2・Ks・Kh）で静的綝り返し（S1）よりも動的（D） が小さくなる傾向を示した。Py を $\delta \mathrm{y}$ で除して求めた剛性 $(\mathrm{k})$ は全 ての仕様で動的（D）の方が高く概ね 1.3〜1.6 倍であったが、小幅 板斜め貼合せ面材（Kh）は 2.3 倍と最も高い比率を示した。

d）終局耐力（Pu）と終局変位 $(\delta \mathrm{u})$

終局耐力（Pu）は、降伏耐力（Py）の傾向と同様で、特に無機系
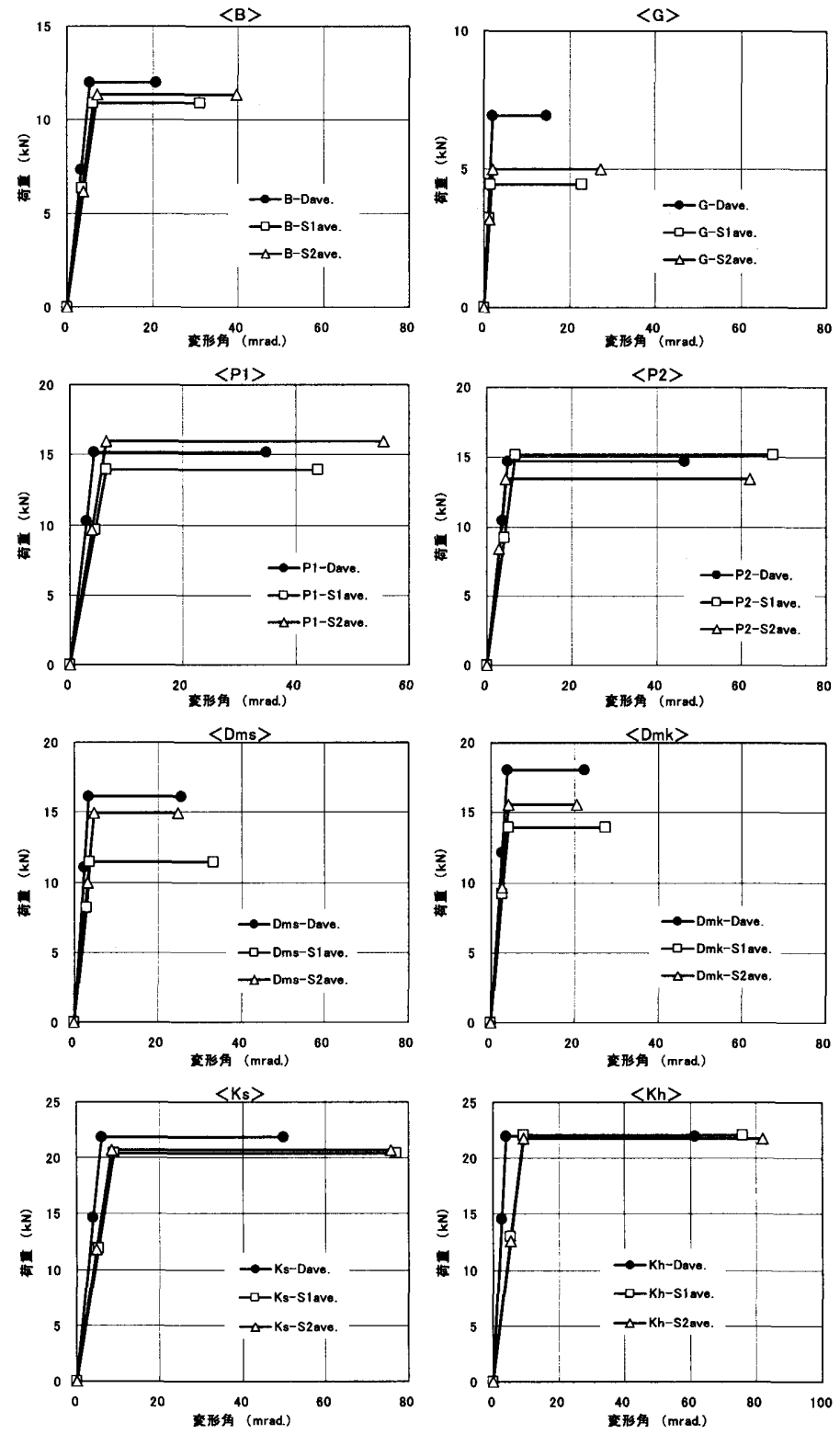

図 9 完全弾塑性モデル ＜試験方法別の平均モデル比較＞

表 5 完全弹塑性モデルと包絡線の特徴点の一覧

\begin{tabular}{|c|c|c|c|c|c|c|c|c|c|c|c|c|c|c|c|c|c|c|c|c|c|c|c|c|c|}
\hline \multirow{2}{*}{\multicolumn{2}{|c|}{$\begin{array}{l}\text { 酎力要素 } \\
\text { 試験方法 }\end{array}$}} & \multicolumn{3}{|c|}{ B } & \multicolumn{3}{|c|}{ G } & \multicolumn{3}{|c|}{$\mathrm{P} 1$} & \multicolumn{3}{|c|}{ P2 } & \multicolumn{3}{|c|}{ Dms } & \multicolumn{3}{|c|}{ Dmk } & \multicolumn{3}{|c|}{ Ks } & \multicolumn{3}{|c|}{ Kh } \\
\hline & & D & S1 & S2 & D & s1 & S2 & D & S1 & S2 & D & S1 & S2 & D & S1 & S2 & D & S1 & S2 & D & S1 & S2 & D & S1 & \$2 \\
\hline O降伏䣯力 $\mathrm{Py}$ & $(\mathrm{kN})$ & 7.34 & 6.32 & 6.16 & 4.42 & 3.22 & 3.20 & 10.30 & 9.66 & 9.67 & 10.47 & 9.17 & 8.35 & 11.08 & 8.20 & 9.95 & 12.15 & 9.16 & 9.63 & 14.63 & 11.88 & 11.83 & 14.53 & 12.96 & 12.59 \\
\hline $\mathrm{OPu} \times(0.2 / \mathrm{Ds})$ & $(\mathrm{kN})$ & 5.88 & 5.47 & 6.86 & 5.01 & 4.33 & 4.93 & 11.65 & 9.89 & 12.90 & 12.18 & 13.15 & $\mid 13.84$ & 11.78 & 9.39 & 9.29 & 11.56 & 9.68 & 8.77 & 17.13 & 16.36 & 16.94 & 23.85 & 17.26 & 17.50 \\
\hline O2/3*Pmax & $(\mathrm{kN})$ & 9.01 & 8.24 & 8.66 & 5.17 & 3.36 & 3.60 & 11.28 & 10.36 & 11.53 & 11.15 & 10.92 & 9.70 & 12.11 & 8.62 & 10.95 & 13.51 & $\mid 10.47$ & 11.45 & 16.78 & 15.57 & 15.44 & 16.93 & 16.74 & 15.97 \\
\hline O見掛け1/120rad & $(\mathrm{kN})$ & 12.26 & 10.55 & 10.39 & 7.41 & 4.78 & 5.03 & 13.17 & 11.85 & 12.56 & 12.78 & 11.73 & 11.87 & 15.92 & 11.38 & $\mid 14.07$ & 18.09 & 13.86 & $15.47 \mid$ & 17.37 & 13.43 & 13.82 & 19.64 & 14.57 & 14.42 \\
\hline 終局䅛力 $\mathrm{Pu}$ & $(\mathrm{kN})$ & 11.95 & 10.90 & 11.31 & 6.94 & 4.44 & 4.99 & $\mid 15.19$ & 13.94 & 15.95 & 14.64 & 15.10 & 13.41 & $\mid 16.13$ & 11.46 & 14.92 & 18.03 & 13.94 & 15.55 & 21.84 & 20.40 & 20.68 & 22.00 & 22.12 & 21.79 \\
\hline 最大荷眘 Pmax & $(\mathrm{kN})$ & 13.51 & 12.36 & 12.98 & 7.75 & 5.04 & 5.40 & 16.92 & 15.53 & 17.29 & 16.72 & 16.37 & 14.55 & 18.16 & 12.93 & 16.42 & 20.27 & 15.71 & 17.17 & 25.17 & 23.36 & 23.15 & 25.40 & 25.12 & 23.96 \\
\hline 降伏变位 $\delta \mathbf{y}$ & (rad.) & $1 / 302$ & $1 / 278$ & $1 / 254$ & $1 / 762$ & $21 / 826$ & $1 / 725$ & $1 / 340$ & $1 / 220$ & $1 / 257$ & $1 / 280$ & $1 / 238$ & $1 / 358$ & $1 / 418$ & $1 / 352$ & $1 / 321$ & $1 / 373$ & $1 / 371$ & $1 / 382$ & $1 / 248$ & $1 / 190$ & $1 / 205$ & $1 / 373$ & $1 / 181$ & $1 / 181$ \\
\hline 降伏点变位 $\delta v$ & (rad.) & $1 / 186$ & $1 / 162$ & $1 / 138$ & $1 / 482$ & $21 / 605$ & $1 / 467$ & $1 / 231$ & $1 / 154$ & $1 / 156$ & $1 / 203$ & $1 / 145$ & $1 / 223$ & $1 / 288$ & $1 / 261$ & $1 / 214$ & $1 / 251$ & $1 / 244$ & $1 / 237$ & $1 / 166$ & $1 / 110$ & $1 / 117$ & $1 / 246$ & $1 / 107$ & $1 / 105$ \\
\hline 釉局变位 $\delta \mathrm{u}$ & (rad.) & $1 / 48$ & $1 / 32$ & $1 / 25$ & $1 / 68$ & $8 \mid 1 / 44$ & $1 / 36$ & $1 / 29$ & $1 / 23$ & $1 / 18$ & $1 / 21$ & $1 / 15$ & $1 / 16$ & $1 / 39$ & $1 / 30$ & $1 / 40$ & $1 / 45$ & $1 / 36$ & $1 / 48$ & $1 / 20$ & $1 / 13$ & $1 / 13$ & $1 / 16$ & $1 / 13$ & $1 / 12$ \\
\hline Pmax時変形角 & (rad.) & $1 / 92$ & $1 / 82$ & $1 / 80$ & $1 / 105$ & $1 / 100$ & $1 / 72$ & $1 / 46$ & $1 / 28$ & $1 / 28$ & $1 / 29$ & $1 / 27$ & $1 / 35$ & $1 / 48$ & $1 / 54$ & $\mid 1 / 47$ & $1 / 52$ & $1 / 60$ & $1 / 81$ & $1 / 32$ & $1 / 20$ & $1 / 21$ & $1 / 34$ & $1 / 21$ & $1 / 18$ \\
\hline 錐造特性係数 Ds & & 0.41 & 0.40 & 0.33 & 0.28 & 0.20 & 0.20 & 0.26 & 0.28 & 0.25 & 0.24 & 0.23 & 0.19 & 0.27 & 0.24 & 0.32 & 0.31 & 0.29 & 0.35 & 0.26 & 0.25 & 0.24 & 0.18 & 0.26 & 0.25 \\
\hline 制性 $k$ & $\begin{array}{l}(\mathrm{kN} / \\
\mathrm{mm})\end{array}$ & 0.82 & 0.65 & 0.58 & 1.24 & 0.98 & 0.86 & 1.29 & 0.79 & 0.92 & 1.08 & 0.81 & 1.10 & 1.71 & 1.06 & 1.18 & 1.67 & 1.25 & 1.36 & 1.34 & 0.83 & 0.89 & 2.00 & 0.87 & 0.84 \\
\hline
\end{tabular}

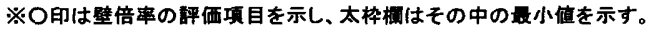

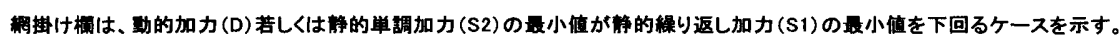


要素（Dms・Dmk・G）が動的試験（D）で高くなる傾向であった。終局 変位 $(\delta \mathrm{u})$ は、全ての仕様で静的繰り返し試験（S1）よりも動的試 験（D）の方が小さな変位となり、動的において早期の荷重低下の傾 向を示した。また、終局変位 $(\delta \mathrm{u})$ は、二つのグループに分けられ る。一つは $\delta \mathrm{u}$ が $1 / 20 \mathrm{rad}$. 以上の大変形を示寸構造用合板 (P2) と 小幅板斜め貼合せ面材 $(\mathrm{Ks} \cdot \mathrm{Kh})$ のグループであり、もう一つは $\delta \mathrm{u}$ が 1/50〜1/30rad.にある筋かい（B)・石高ボード（G）・火山性ガラス 質複層板（Dms·Dmk）のグループである。これは破壊性状によって分 類が可能である。「P2・Ks・Kh」は、面材自体は壊れずに釘が引き抜け て壊れるタイプ（接合具破壊）で、「B·G·Dms·Dmk」は耐力要素自体 が座屈破断や割れによって壤れるタイプ（母材破壊）である。また、

構造用合板（P1）はパンチアウト破壤であるがパンチアウトには釘 の引き拔けが伴うため母材と接合具破壊の混在となり中間的な変位 となった。破壊性状は、終局変位 $(\delta \mathrm{u})$ に大きく影響している。

\section{e）構造特性係数（Ds）}

構造特性係数（Ds）の值が、静的繰り返し試験（S1）に対して大 きくなり降伏後の変形能力が小さくなる傾向を示したのは、石梙ボ ード（G）の動的試験（D）と火山性ガラス質複層板（Dms·Dmk）の静 的単調加力試験（S2）であった。他の仕様と異なり、石育ボード (G) は動的試験（D）で終局変位（ $\delta \mathrm{u} ）$ は小さくなるのに対し降伏点変 位（ $\delta \mathrm{v} ）$ は若干大きくなり、火山性ガラス質複層板 $(\mathrm{Dms} \cdot \mathrm{Dmk})$ は 静的単調加力（S2）で降伏点変位（ $\delta \mathrm{v} ）$ は若干大きくなるのに対し 終局変位 $(\delta \mathrm{u})$ は小さくなるのが原因である。ほかは動的試験 (D) で構造特性係数（Ds）が若干大きくなる傾向を示す仕様が多い。ま た、脆性的な破壊をした筋かい（B）の Ds は、0.33〜0.41 とほかと 比べて大きい。

\section{6. まとめ}

5 種類 8 仕様の木造軸組工法耐力壁に対して、静的と動的の 2 種 類の加力方法について、それぞれ繰り返しと単調の合計 4 種類の試 験を行った。「静的加力と動的加力の違いと「繰り返しの影響」に ついて比較分析を行い、次のようなことがわかった。

- 全ての仕様で動的試験の荷重は、小変形領域から概ね $1.1 \sim 1.5$ 倍 の比で静的試験の荷重を上回った。特に、無機系要素 $(G \cdot D m s \cdot D m k)$ は $1.3 〜 1.5$ 倍と高い比を示した。

・最大荷重は、木質系要素（B・P1·P2・Ks・Kh）ではほぼ同じで、無機 系要素（G·Dms·Dmk）では動的が上回る傾向であった。

・全ての仕様で完全弾塑性モデルの終局変位（ $\delta \mathrm{u} ）$ は、動的の方が 小さく早期の荷重低下の傾向を示し、降伏変位（ $\delta \mathrm{y} ）$ も特に木質 系要素 $(\mathrm{B} \cdot \mathrm{P} 1 \cdot \mathrm{P} 2 \cdot \mathrm{Ks} \cdot \mathrm{Kh})$ で動的の方が小さくなる傾向を示した。 ・破壊性状は、木質系面材 $(\mathrm{P} 2 \cdot \mathrm{Ks} \cdot \mathrm{Kh})$ が動的で釘引き抜け主体から パンチアウト混在に変化した。その他は静的と同じであった。

・壁倍率の評価項目において、静的綝り返し加力試験の結果は概ね 安全側であったが、単調加力が下回るケースもあり注意を要する。
・繰り返しによる影響は、構造用合板（P1）と無機系要素（G·Dms Dmk）の静的加力で見られ、最大荷重で約 10〜20\%低下した。 なお、今後は接合部レベル（釘・ねじ）の加力試験などを行い静 的・動的性状の検討を行う予定である。
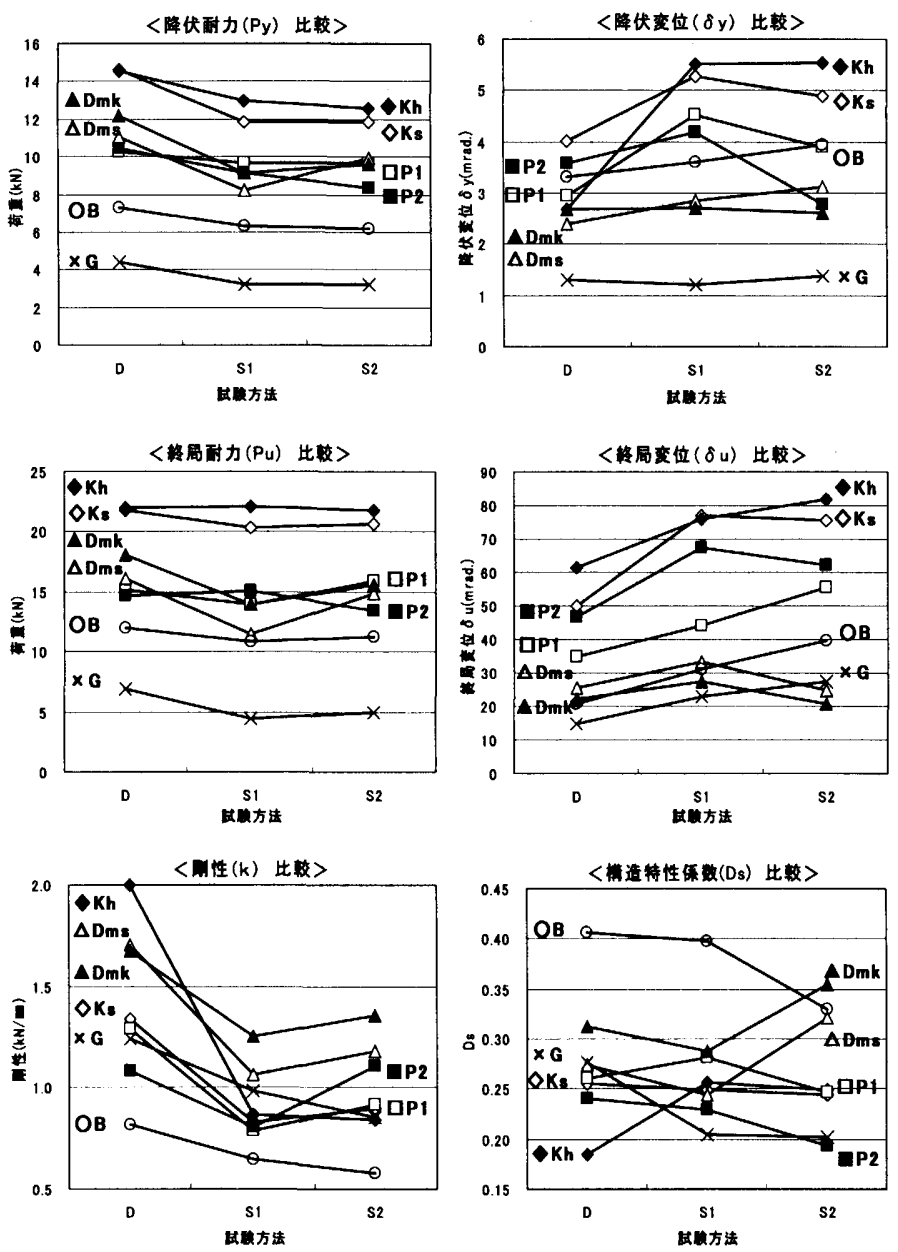

図 10 完全弾塑性モデルの特徽点の比較

\section{至考文献}

1)町田健一、綿引誠、大橋好光、金井正博、高橋浩一、中野一郎：各種耐力壁 による静的・動的加力試験（その 1 3)、日本建築学会大会学術講演梗概集 (東海)、構造而、pp99-104、2003. 9

2) 坂本功、大橋好光、宮野道雄、土开正、村上雅英、宮澤健二 : 阪神大震災に 見る木造住宅と地震、鹿島出版会、1997.4

3) 例えば、(財) 日本住宅・木材技術センター：木造の耐力壁及びその倍率性能 評価業務方法書、2001. 5

4) 山田真澄、鈴木祥之、後藤正美、清水秀丸：単位木造フレームを用いた動的・ 静的実験による木造軸組の耐震性能評価、日本建築学会構造系論文集、第 582 号、pp95-102、2004. 8

5）箕輪親宏、山口修由：振動台実験による木造耐力壁の動的耐震性能評価 第 3報、合板釘打耐力壁の荷重速度効果と動的降伏点、日本建築学会大会学術 講演梗概集 (九州)、構造吕、pp149-150、1998.9

6) 塩沢伸明、那須秀行、町田健一、石山央樹、大橋好光：面材耐力壁を用いた 木造軸租構法住宅の実大静加力実験（その2）壁の加算則の検証、日本建築 学会大会学術講演梗概集（北陸）、構造III、pp111-112、2002.8

7) (財) 日本住宅・木材技術センター：木造軸組工法住宅の許容応力度設計、 pp146、2001. 12

8)軽部正彦、原田真樹、林知行 : 荷重変形曲線のモデル化とその問題点共有の ための提案 特徴点抽出の自動化ツールについて、日本建築学会大会学術講 演梗概集（関東）、構造吕、pp215-216、2001.9

（2004年12月 8 日原稿受理，2005年 4 月 14 日採用決定) 